\title{
Conceptualization of the Sensory Experience: A Frame-Based Approach
}

\author{
Georgiy B. Blinnikov \\ Lomonosov Moscow State University, Moscow, Russia \\ *Corresponding author. Email: georgijblinnikov@gmail.com
}

Background. The search for reliable means of establishing relations between sensory qualia and their conceptualization in language has given rise to several approaches, both philosophical and psychophysical. This paper gives a short account of today's approaches to the problem and presents a framebased approach, which may be superior to other methods.

Objective. To evaluate the effectiveness of the frame-based approach to the conceptualization of sensory qualia in language. The semantic field "Loud" in the Italian language is analyzed, as it offers a unique case: Italian does not have a lexeme whose main meaning would be translated into English as "loud" or into Russian as "громкий" (gromkii)).

Design. In the field "Loud", nine adjectives were analyzed by means of dictionary definitions, frequency in the Italian language corpus, and native speakers' usage.

Results. The findings reveal a frame structure of the field consisting of 11 frames, which can be grouped into two large entities: sounds proper and objects that emit sounds. The parameters that underpin the frame structure are vocal/non-vocal, intentional/spontaneous, explosive/non-explosive, one source/multiple sources, and natural/artificial. Another important result is a more accurate description of lexemes involved in the current field (the main adjectives are alto, forte, and rumoroso).

Conclusion. The frame-based approach provides an effective means of studying the relationship between sensory qualia and their conceptualization in language.

ISSN 2074-6857 (Print) / ISSN 2307-2202 (Online)

(c) Lomonosov Moscow State University, 2019

(C) Russian Psychological Society, 2019

http://psychologyinrussia.com

Keywords: sensory experience, frame-based approach, conceptualization of qualia, corpora 


\section{Introduction}

The task of conceptualizing sensory experience has been undertaken by many sciences including psychology, linguistics, philosophy, and neuroscience. In a way, this problem was posed as early as the 17th century by John Locke, who postulated that the main source of knowledge about the world for man is experience. He wrote that our "understandings" are supplied with observation "employ'd either about external, sensible Objects; or about the internal Operations of our Minds" (Fuller, Stecker \& Wright, 2000, p. 67). Despite a long history of debate and research, the question of how simple ideas generate complex ideas and how they are conceptualized remains unanswered. Russian psychology sees this type of process as a transformation of natural mental functions into higher ones. In the case of sensory experience, direct sensory sensations are transformed into concepts of qualities of the outside world. According to Lev Vygotsky (1978/1930), language tools play a crucial role in this transformation. However, an elegant principle of the development of higher mental functions confronts the problem of linguistic ineffability of sensory experience (Levinson \& Majid, 2014).

Nowadays, philosophers reflecting on the nature of sensory experience usually employ the term qualia understood as "certain features of the bodily sensations especially, but also of certain perceptual experiences, which no amount of purely physical information includes" (Jackson, 1982, p. 273). Qualia are not physical characteristics of objects, but are part of the consciousness of the subject who perceives objects. On the one hand, they are reportable; on the other, they represent the world (Chalmers, 1996). However, by Dennett's definition, qualia cannot be directly reported from person to person; they can be experienced only because of one's own perception (Dennett, 1991). In fact, it has been shown that physical characteristics of the environment, subtly distinguishable by human sensory systems, cannot be differentiated easily by language (Agrillo \& Roberson, 2009; Levinson \& Majid, 2014).

But even if a sensory quality cannot be fully shared with others, people try to find language tools to convey at least some of its features. The need to share subjective sensory experience with another person leads to reflection and, eventually, to the categorization and conceptualization of this experience. It is not by chance that in a number of philosophical concepts, language is considered a kind of roadmap. L. Wittgenstein wrote that what one person sees and what the other sees when they perceive the color of an object may differ, but when both people associate this color with the word "red", certain similarities can be found in their sensations (Wittgenstein, 1953). Different points of view on linguistic ineffability and the possibilities of conceptualizing sensory experience prompt the search for new solutions of this problem.

We can identify three approaches to the relationship between sensory experience and language. Their common goal is to discover the connection between the world of sensations and the world of words, but their methodological frameworks differ considerably.

In the first approach, researchers study the naming of sensations. Subjects are offered a series of physical stimuli that they are to name; then their designations are analyzed. In their classic paper, B. Berlin and P. Kay (1969) found a correlation be- 
tween the number of color terms in a language and what these terms should be. For example, if a language has only three terms for colors, they would be black (dark), white (light), and red. One hundred and ten unwritten languages were studied; their speakers were given chips of different colors which they were asked to name.

G. Senft, who studied color and taste terms in the Kilivila language spoken on one of the islands of Papua New Guinea, used color chips and containers with sour, bitter, sweet, or salty substances. Sixty subjects (between the ages of 4 and 75) were asked to name what they felt or saw (Senft, 1987). Eventually, the technique became widespread. In particular, some ethnographic and socio-anthropological studies employed the approach while investigating the sound landscape - i.e., how the audible environment is presented in different languages (Keil, Blau, Keil, \& Feld, 2002).

These ethno-linguistic studies utilize the so-called quasi-psychophysical approach, which identifies language means used to denote sensory experience, and their limitations, making it possible to relate different zones of the sensory spectrum to their names. However, this methodology neglects many aspects of the conceptualization of sensory experience, notably the influence of culture and the specifics of the human activity. Not surprisingly, O. Le Guen, who examined the naming of color, texture, and other areas of sensory experience in languages of the Yucatan Indians, concluded that the sensory language is not influenced by material culture and reflects only the characteristics of sensory systems and tastes of the people (Le Guen, 2011).

The second approach is the study of the relationship between language and concepts. A renowned expert in the field of ethnography, Steven Tyler, believed that for comparing sensory systems in different cultures, psychophysical and psychophysiological knowledge is not of particular importance. Anthropologists and linguists can focus on studying differences between concepts that describe the world around them (Tyler, 1986). This approach is advocated by A. Wierzbicka and her followers. Adherents of this school are trying to identify a universal set of semantic primitives, or primes - that is, elementary words that exist in all languages. Using only the words from this set, one can, hypothetically, define any word in any language (Wierzbicka, 2010). The attempt to reduce general concepts to elementary sensations is promising, but it faces several difficulties. First, absolute synonyms are a rarity, and this certainly applies to equivalents in different languages; therefore, it is hardly possible to speak of a universal meta-language or a single lexical set for all languages, as the semantics of the units of the set are different in each language. The choice of primitives in some cases and the definition of individual words are also debatable.

The third, frame-based, approach could be seen as an alternative to the abovementioned approaches. The basic idea of frame semantics, proposed by C.J. Fillmore (1977), is that word meanings are best described in terms of the schematization of events and objects, based on experience. Such a scheme, referred to as a semantic frame, includes the event, its participants and circumstances, and establishes links between them (cf. Ruppenhofer, Boas \& Baker, 2017). Ideas of frame semantics were first put to the test in the systematic analysis of lexicons in English (Fontenelle, 1997; Heid, 1996), but similar projects were conducted later for Japanese (Ohara, 2015), German (Burchardt et al., 2009), Brazilian Portuguese (Salomão, Torrent, \& Sampaio, 2013), Finnish (Lindén, Luukkonen, Laine, Roivainen, 
\& Väisänen, 2017), Italian (Luraghi, 2015), and French (Candito et al., 2014). In Russia, this approach has been developed by the Lexical Typology group headed by E. Rakhilina, although frame semantics here has been given its own interpretation (Rakhilina, 2016).

The object of research is the semantic field - i.e., a group of words with a single, integral semantic function, which represents a particular class of objects, phenomena or, as in our case, qualities of the outside world. In this framework, these are always synonymous lexemes, such as verbs that have a seme of movement (e.g., walking, running, swimming, rolling [Kobozeva, 2000; Kuznetsov, 1990]), a seme of temperature (Luraghi, 2015), a seme of a surface irregularity (Kashkin 2013), etc.). At first glance, the study of synonyms should yield rather poor semantic results; after all, the only thing that is interesting about lexemes with the same semantics is their existence and their quantity. However, as was shown by A. Apresyan (1995), absolute synonyms are very rare in a language. It would be correct to talk about quasi-synonyms and say that words are semantically similar rather than semantically identical. This allows us to compare a word with many other words and define their relative similarity. For the frame approach, it is crucial to identify contexts for which the use of one quasi-synonym is prototypical and the use of another quasisynonym is restricted.

The frame acts as an invariant of certain contexts that are lexically opposed to other contexts. In the formal approach, it can be described as a situation that represents the outside world with a number of assigned syntactic roles. Rakhilina gives her own definition of the frame: It is a general situation that has fixed prototypical participants (Rakhilina \& Reznikova, 2013). The identification of such situations is based on the compatibility of the lexemes under study with the surrounding context or, in other words, their ability to form certain collocations. For example, the semantic field of surface irregularities in the Italian language has such frames as "large, visually perceptible roughness", denoted by the lexemes ruvido 'rough' and scabro 'rough', and "roughness and rigid structure of the object", denoted only by the lexeme ruvido 'rough'. Thus, the second frame is based on the use of ruvido and restriction on the use of scabro. It should be emphasized that it is the semantic restrictions on compatibility, not the morphosyntactic ones, which are relevant, as they make it possible to determine semantic differences between situations (frames).

The collocations that the lexemes form are determined by different methodological techniques: primarily the use of dictionaries, analysis of the frequency of collocations in language corpora, and surveys of native speakers. Each semantic field has a specific set of frames and a finite set of lexemes that denote these frames. The frame structure of the semantic field and its lexical structure are visualized in semantic maps.

The object of many studies is sensory vocabulary: qualities of smoothness and roughness of the surface (Blinnikov, 2013; Kashkin, 2013); temperature (Luraghi, 2015); tight and elastic qualities (Baskakova, 2015), and others. Papers on the metaphoric shifts between different sensory zones could also be mentioned (e.g., Blinnikov, 2015). Both the languages of one family (for example, the Uralic languages) and languages belonging to different families (Indo-European, Semitic, Kartvelian, and others) are studied. 


\section{Methods}

\section{Rationale and Method Applicability}

The goal of this study is to analyze the semantic field of loudness above the norm ("Loud") in Italian. The basis of our work is the methodology employed by the Lexical Typology group; however, at one point our research is different. This group investigated a large number of languages belonging to different language families, whereas in the present case, the semantic field is studied only in one language (Italian), with Russian and English as background languages. Certainly, this study cannot claim to identify the universal frame structure of the field, but it still can provide meaningful results, because a significant area of the studied semantic field is covered by lexemes functioning in their metaphorical meaning. For example, the Italian language does not have a lexeme whose main meaning would be translated into English as "loud" or into Russian as "громкий" (gromkiu)). The first consequence of this circumstance is the rich synonymy of lexemes in this field. This is predictable, as the metaphorical meaning depends on both the properties of the source zone and those of the target zone (Lakoff \& Johnson, 2008). As the sounds differ in many parameters (to be described below), the metaphorical meanings of one or two lexemes are incapable of including the whole multitude of such parameters. Hence we can deduce a second consequence: The need to fill the field with lexemes in their figurative meaning activates the semantic field parameters that exist implicitly in the human mental world, but are not expressed in language systems with lexemes denoting a high degree of loudness in their nominative meaning. Such parameters can potentially be detected in other languages. However, even if some qualities can be found only in the Italian language, it is noteworthy that they, and not others, are reflected in the language that experiences this kind of lexical "famine".

\section{Research Design}

The first step in our research is to define the boundaries of the studied semantic field. Initially, the field boundaries are based on the native language vocabulary, but when moving to other languages, these boundaries can shift significantly (Rakhilina \& Prokofieva, 2004).

The next step is a search for translation equivalents of the initial lexemes in $\boldsymbol{b i}$ lingual dictionaries. The obtained list of words is verified via text corpora. Corpus contexts in which these lexemes are used are compared to each other within the same language and undergo semantic analysis, which reveals parameters by which these contexts differ. The Sketch Engine was used as the Italian text corpus (Kilgarriff, 2014). It consists of written texts (both literary and journalistic) representing the modern Italian language, and contains 2.5 billion word tokens. It is the largest corpus of the Italian language today and can be considered representative for the purposes of this research.

In the next step, these data help compile questionnaires for native speakers. The survey was conducted on a sample of speakers of the Italian language who were studying linguistics in Italian universities or had a scientific degree in linguistics (20 people in total; 7 males, 13 females; the average age of subjects was 35.2 years). 
Subjects were selected based on their origin: The south, center, and north of the country were evenly represented. Subjects provided information about themselves: surname, first name, gender, age, place of birth, and education. The questionnaire included a list of adjectives from the semantic field and a number of sentences with omissions that the subjects were asked to fill in. The sentences were of the following type: Ieri si poteva sentire la musica ... dalla sua casa. I vicini non possono dormire. "Yesterday ... music played in his house. Neighbors could not get to sleep." Subjects were asked to select one or more adjectives from the list to fill in the gaps. If none of the adjectives was suitable, subjects were allowed to suggest their own word which, in their opinion, better fit the context or to leave the gap blank if no word seemed appropriate to them.

\section{Results}

Our inquiry revealed two types of frames. Type A includes phenomena of a fully or partially acoustic nature (for example, a song, a voice, or a noise) that in Russian are denoted by the adjective loud; Type B includes objects that make sounds louder than the norm (a company of people, a waterfall, a street), i.e., that create a loud noise. In Russian, nouns denoting these concepts are collocated with the adjective shumnyi 'noisy'. In English, some of them are described by the adjective noisy, while others are denoted by the adjective loud.

\section{Dictionary Analysis}

The sample includes a total of nine adjectives: forte 'strong', alto 'high', sonoro 'sonorous', sonante 'sonorous', rumoroso 'noisy', fragoroso 'uproarious', chiassoso 'noisy, rowdy', clamoroso 'resounding, noisy', assordante 'deafening. The final list contains the nouns that denote acoustic phenomena or objects emitting sounds, whereas their collocations with the studied adjectives generate significant phenomena. Thus these nouns either form a large number of collocations with one or several adjectives, or, contrary to the initial hypotheses, do not form any meaningful number of collocations (e.g., radio 'radio'). In other words, the final list includes nouns that correspond to the frames. The following nouns entered the final list: voce 'voice', grido 'shout, scream', musica 'music', risata 'laughter', rumore 'noise', battito 'knock', applausi 'applause', discorso 'speech', conversazione 'conversation', ambiente 'environment', via 'street', sala 'hall', cascata 'waterfall', compagnia 'company (of people)', gruppo 'group (of people)', bambino 'child', radio 'radio', sveglia 'alarm', motore 'engine'.

The nouns listed above fall into two groups. Type A includes the following frames (nouns representing them are given in parentheses):

1. Vocal, intentional sounds (voce 'voice, grido 'shout, scream');

2. Intentional non-vocal sounds (musica 'music');

3. Vocal, spontaneous, explosive sounds (risata 'laughter');

4. Spontaneous, non-vocal sounds (rumore 'noise, battito 'knock');

5. Explosive, non-vocal sounds (applausi 'applause');

6. Vocal interaction (discorso 'speech', conversazione 'conversation'). 
Type B includes the following frames (nouns representing them are given in parentheses):

1. Locations (ambiente 'environment', via 'street', sala 'hall');

2. Objects that emit explosive sounds (cascata 'waterfall');

3. People (compagnia 'company (of people)', gruppo 'group (of people)', bambino 'child');

4. Sound devices (radio 'radio', sveglia 'alarm');

5. Noisy machinery (motore 'engine').

\section{Corpora Analysis}

The analysis of the text corpora yielded the following results (see Tables 1 and 2). The adjective forte 'strong' collocates with all the nouns of Type A (acoustic objects/phenomena; 1,377 collocations in total), except for the lexeme conversazione 'conversation'. When used with the noun discorso 'speech', it is used in the figurative meaning 'able to produce a powerful effect on the listener'. We find the largest number of collocations in the frame "Vocal, intentional sounds" (809 hits).

The adjective alto 'high' collocates with almost all the Type A nouns, with the exception of the noun conversazione 'conversation'. When used with the noun discorso 'speech', it is used in its figurative meaning 'lofty'. However, only interaction

Table 1

Corpus frequency of collocations of field adjectives with nouns denoting acoustic phenomena (Type A)

\begin{tabular}{|c|c|c|c|c|c|c|c|c|c|}
\hline \multicolumn{10}{|c|}{ Groups of nouns } \\
\hline Adjective & 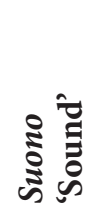 & 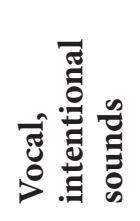 & 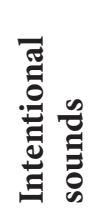 & 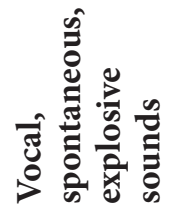 & 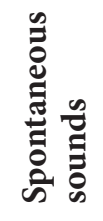 & 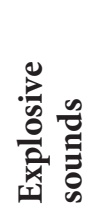 & 莺 & हैँ & $\%$ \\
\hline Forte & 142 & 809 & 76 & 22 & 247 & 21 & 60 & 1,377 & 15.09 \\
\hline Alto & 64 & 5,229 & 268 & 1 & 9 & 1 & 66 & 5,638 & 61.77 \\
\hline Sonoro & 8 & 92 & 1 & 80 & 8 & 6 & 30 & 225 & 2.47 \\
\hline Sonante & 1 & 10 & 0 & 4 & 0 & 1 & 1 & 17 & 0.19 \\
\hline Rumoroso & 17 & 3 & 28 & 20 & 4 & 1 & 4 & 77 & 0.84 \\
\hline Fragoroso & 14 & 6 & 12 & 211 & 37 & 161 & 2 & 443 & 4.85 \\
\hline Chiassoso & 6 & 20 & 5 & 5 & 2 & 0 & 1 & 39 & 0.43 \\
\hline Clamoroso & 1 & 14 & 0 & 14 & 0 & 1 & 2 & 32 & 0.35 \\
\hline Assordante & 100 & 55 & 293 & 5 & 813 & 12 & 1 & 1,279 & 14.01 \\
\hline Total & 353 & 6,238 & 683 & 362 & 1,120 & 204 & 167 & 9,127 & 100 \\
\hline$\%$ & 3.87 & 68.35 & 7.48 & 3.97 & 12.27 & 2.23 & 1.83 & 100 & - \\
\hline
\end{tabular}

Note: Each cell shows the number of collocations for the given adjective (in the left column) and the given group of nouns (column head). 
Table 2

Corpus frequency of collocations of field adjectives with nouns denoting objects that emit sounds (Type B)

\begin{tabular}{|c|c|c|c|c|c|c|c|}
\hline \multicolumn{8}{|c|}{ Groups of nouns } \\
\hline Adjective & 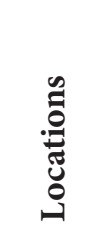 & 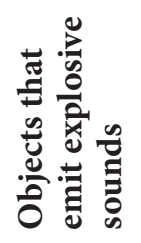 & 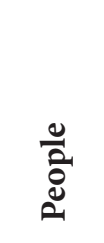 & 龸若 & 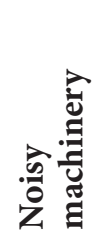 & 큘 & $\%$ \\
\hline Forte & N/A & N/A & $\mathrm{N} / \mathrm{A}$ & 5 & N/A & 5 & 0.75 \\
\hline Alto & $\mathrm{I} / \mathrm{M}$ & $\mathrm{I} / \mathrm{M}$ & $\mathrm{I} / \mathrm{M}$ & 8 & $\mathrm{I} / \mathrm{M}$ & 8 & 1.19 \\
\hline Sonoro & 290 & 3 & 5 & 2 & 17 & 317 & 47.31 \\
\hline Sonante & 1 & 0 & 1 & 0 & 0 & 2 & 0.31 \\
\hline Rumoroso & 150 & 1 & 29 & 1 & 48 & 229 & 34.18 \\
\hline Fragoroso & 0 & 21 & 2 & 0 & 0 & 23 & 3.43 \\
\hline Chiassoso & 12 & 0 & 62 & 0 & 0 & 74 & 11.04 \\
\hline Clamoroso & 1 & 0 & 0 & 0 & 0 & 1 & 0.15 \\
\hline Assordante & 4 & 4 & 0 & 1 & 2 & 11 & 1.64 \\
\hline Total & 458 & 29 & 99 & 17 & 67 & 670 & 100 \\
\hline$\%$ & 68.36 & 4.33 & 14.78 & 2.53 & 10 & 100 & - \\
\hline
\end{tabular}

Notes. Each cell shows the number of collocations for the given adjective (in the left column) and the given noun (column head). $N / A=$ not applicable; $I / M=$ improper meaning.

with the noun suono 'sound' (64 hits) and the frames "Vocal, intentional sounds" (5,229 hits) and "Intentional sounds" (268 hits) can be recognized as significant. Despite an extremely large number of references to the collocation of the adjective alto 'high' with voce 'voice' ("Vocal, intentional sounds"), the overwhelming part of them is the collocation a voce alta 'in a loud voice', 'aloud' (the synonym ad alta voce has 11,127 hits).

The largest number of collocations with the lexeme sonoro 'sonorous' are found in the frames "Vocal, intentional sounds" (92 hits) and "Vocal, spontaneous, explosive sounds" ( 80 hits). With the rest of the stimuli, collocations are few (the word suono 'sound', "Intentional sounds", "Spontaneous sounds", "Explosive sounds") or the adjective is used in the meaning 'acoustic' (noun discorso 'speech' and all the Type B nouns).

Among the adjectives under scrutiny, sonante 'sonorous' is the least used. The lexeme rumoroso 'noisy' collocates with both Type A and Type B. However, there are fewer collocations with the Type A nouns compared to Type B (77 hits against 229 hits). In Type A, it predominantly collocates with the frames "Vocal, spontaneous, explosive sounds" (20 hits) and "Intentional sounds" (28 hits). In Type B, 150 collocations were in the frame "Locations", 29 collocations in the frame "People", and 48 collocations in the frame "Noisy machinery". Only one collocation was 
found in the frame "Sound devices" (with the noun radio 'radio') and one collocation in the frame "Objects that emit explosive noises".

The adjective fragoroso 'uproarious' collocates mainly with the Type A nouns (443 hits in total); in Type B, we found only 23 collocations (21 of them with one noun). The lexeme actively interacts with the frames "Vocal, spontaneous, explosive sounds" (211 hits), "Explosive sounds" (161 hits), and "Objects that emit explosive sounds" (21 hits).

The adjective chiassoso 'noisy, rowdy' mainly collocates with the frame "People" (62 hits) and the frame "Vocal, intentional sounds" (20 hits).

The number of collocations with clamoroso 'resounding, noisy' and stimuli was insignificant - with the exception of the frames "Vocal, intentional sounds" (14 units) and "Vocal, spontaneous, explosive sounds" (14 units). However, in the frame "Vocal, intentional sounds", the adjective is used in its metaphorical meaning: The collocation voce clamorosa means 'scandalous rumor'.

The lexeme assordante 'deafening' actively interacts with Type A (1,279 collocations) and almost does not interact with Type B (11 collocations).

The analysis confirms the rare usage of the adjectives sonante 'sonorous' and clamoroso 'resounding, noisy'. Alto 'high', forte 'strong', and assordante 'deafening' are the primary adjectives that collocate with the frames of Type A.

\section{Survey of Native Italian Speakers}

Analysis of the questionnaires revealed the following:

About a permanent voice quality which communicates that its owner is in the house (Voce): $60 \%$ forte 'strong', $15 \%$ alto 'high', $15 \%$ “Other”, assordante 'deafening' $10 \%$. The category "Other" comprises the adjectives tonante 'thunderous' and squillante 'resonant'.

About a high-pitched voice (Voce): 70\% “Other" (adjectives acuto 'shrill', squillante 'resonant'), 30\% alto 'high';

In the fixed phrase 'in a loud voice' ('aloud') (Voce): $100 \%$ alto 'high';

About a piercing voice that makes the ears ring (Voce): 65\% "Other" (stridulo 'sharp', acuto 'shrill', squillante 'ringing', 30\% assordante 'deafening', 5\% clamoroso 'resounding, noisy');

About a sound louder than the norm (Suono): 70\% alto 'high', $20 \%$ forte 'strong', 5\% assordante 'deafening', 5\% "Other" (acuto 'shrill');

About deafening sounds (Suoni): 50\% assordante 'deafening', 20\% forte 'strong', $20 \%$ "Other" (acuto 'shrill'), 10\% alto 'high';

About music that keeps you from sleeping (Musica): 60\% alto 'high', $40 \%$ forte 'strong';

About loud laughter (Risata): 85\% fragoroso 'uproarious', 5\% forte 'strong', 5\% assordante 'deafening', 5\% "Other" (dirompente 'explosive');

About laughter that sounds like the ringing of a bell (Riso): 90\% "Other" (squillante 'ringing', stridulo 'sharp'), 5\% sonoro 'sonorous', 5\% chiassoso 'noisy, rowdy';

About a hall with good acoustics (Sala): 95\% "Other" (subjects were undecided), $5 \%$ sonoro 'sonorous';

About a noisy urban environment (Ambiente): 95\% rumoroso 'noisy', 5\% assordante 'deafening';

About loud applause (Applausi): 80\% fragoroso 'uproarious', 10\% clamoroso 'resounding, noisy', 10\% “Other" (scrosciante 'thunderous'); 
About a loud company (Comitiva): 60\% chiassoso 'noisy, rowdy', $40 \%$ rumoroso 'noisy';

About a child who is too loud (Bambino): $50 \%$ rumoroso 'noisy', $35 \%$ chiassoso 'noisy, rowdy', 10\% assordante 'deafening', 5\% "Other" (subjects were undecided);

About a waterfall that produces a noise so loud that people cannot hear each other talk (Cascata): 70\% rumoroso 'noisy', 20\% fragoroso 'uproarious', 10\% assordante 'deafening';

About a square filled with people (Piazza): 35\% rumoroso 'noisy', 35\% chiassoso 'noisy, rowdy', 20\% “Other" (caotico 'chaotic', some subjects were undecided), 10\% assordante 'deafening';

About a radio that is too loud (Radio): 50\% alto 'high', 25\% "Other" (subjects were undecided), 15\% forte 'strong', 10\% rumoroso 'noisy';

About an alarm clock that wakes up the whole house (Sveglia): 20\% "Other" (fastidioso 'annoying', penetrante 'penetrating', some subjects were undecided), 35\% assordante 'deafening', 20\% rumoroso 'noisy', 15\% chiassoso 'noisy, rowdy', $5 \%$ alto 'high', $5 \%$ forte 'strong'.

The main adjectives that collocate with the Type A nouns are alto 'high' and forte 'strong. The main adjective that collocates with the Type B nouns is rumoroso 'noisy'. Nouns denoting a person or a group of people also collocate with the adjective chiassoso 'noisy, rowdy'. The adjective sonoro 'sonorous' hypothetically can collocate with the noun sala 'hall' in the meaning 'a hall with good acoustics' (sala sonora). Collocations in the frame "Sound devices" (radio 'radio' and sveglia 'alarm') were found to be unstable: Subjects named adjectives usually used with the Type A nouns (in this case we are dealing with a metonymic shift from the sound produced by the device to the device itself) and also adjectives usually used with the Type B nouns. Some subjects noted that the use of adjectives with these nouns is incorrect.

In the context of overly loud sound, subjects selected alto 'high' and forte 'strong' in addition to the basic adjective assordante 'deafening'. Some subjects suggested the adjective assordante 'deafening' in other contexts when they thought that the sound was too loud.

Generally, the subjects' answers confirmed the patterns found in the corpus analysis of collocations.

\section{Discussion}

The difference between Type A and Type B is shown in Figure 1.

Type A and Type B reveal semantic oppositions which form the basis for the conceptualization of loudness perception. Two categories emerge: sounds proper and objects that emit sounds. In the first category, intentional sounds are opposed to random sounds (subjects' intentions); explosive sounds are opposed to smooth sounds (sound properties); and vocal sounds are opposed to the rest (means of sound production). The second category includes oppositions between the natural and the artificial. The natural is subdivided into locations (a square or a street), natural objects (a waterfall), and people (a woman or a child). The artificial has two subcategories: mechanisms created to produce sounds (a radio or TV set) and mechanisms producing sounds as a side effect (an engine). The frame structure is shown on the semantic map (see Fig. 2). 


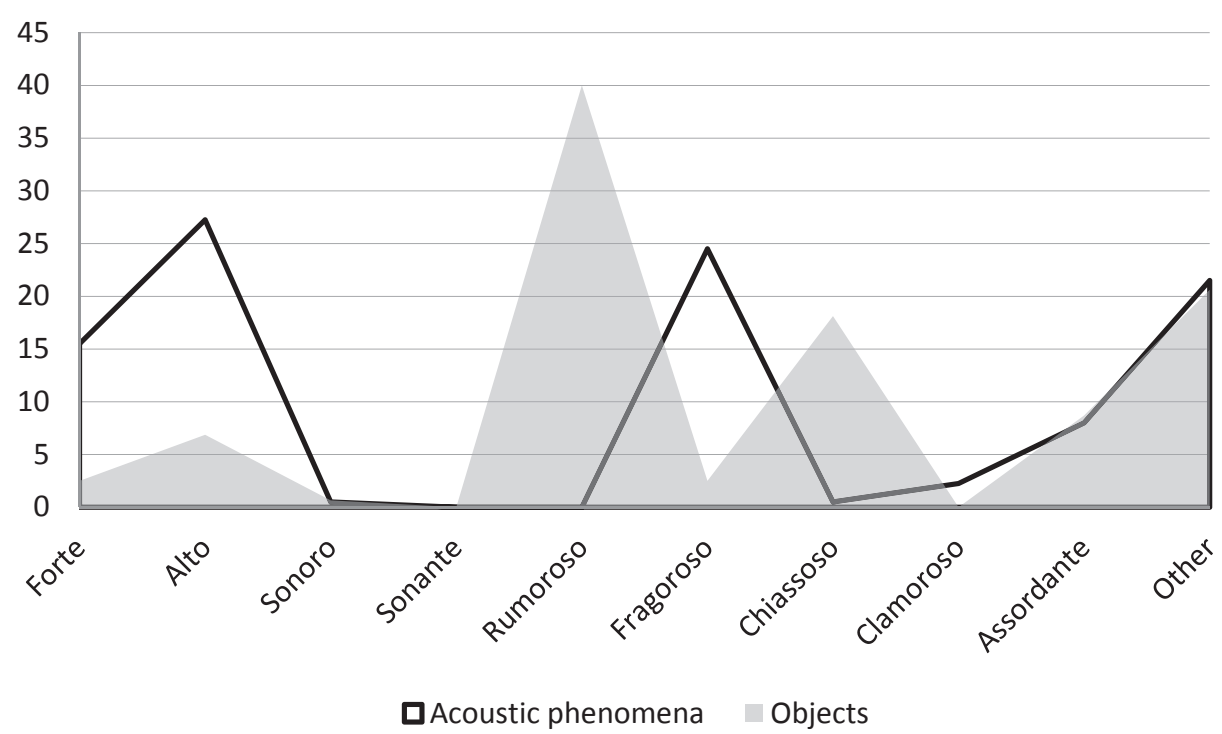

Figure 1. Subjects' responses to the questionnaire.

Note: Frequency (\%) of usage of the field adjectives in frames related to acoustic phenomena (black \& white) and frames related to objects that emit sounds (grey).

The frame-based analysis is also a powerful instrument to study the semantics of individual words. Two lexemes forte 'strong' and alto 'high' are of special importance, as they are, on the one hand, the main designators of the Type A frames (acoustic phenomena) and, on the other, are used in their figurative meaning.

The first meaning of the Italian word forte is 'strong'. A similar meaning is found in the Russian collocation sil'nyı shum 'strong noise' (i.e., 'loud'). The English collocation strong voice could be interpreted as 'loud voice', as well, if we consider the first meaning of the word voice ("the sounds that someone makes when they speak" [Rundell, 2012]).

Such collocations are possible due to the fact that the word strong intensifies the quality of an object with which it collocates (or more precisely a noun that it denotes). The range of concepts that strong can intensify varies in different languages, but obviously this lexeme has this potential. Having no lexeme whose nominative meaning would be an increased or noticeable loudness (Latin also lacked such a word), the language employs a lexeme potentially capable of "intensifying" any attribute and of entering a wide range of collocations (according to the Treccani Italian dictionary [Duro, 2008], forte 'strong' has nine meanings). Another factor contributing to the emergence of a new meaning is the correlation between intensification of a process and increase in loudness of the accompanying sound. This works for such processes as laughing or coughing: The more energy one uses, the louder these processes are - hence such collocations as risata forte 'strong laughter' and tosse forte 'strong cough'. Certainly, collocation restrictions are imposed even when forte 'strong' is used in its first meaning. For example, forte rissa 'strong fight' is most likely impossible.

When forte means 'loud', it cannot collocate with the Type B nouns (objects and people making noise; locations filled with noise): compagnia forte 'strong company', via forte 'strong street', motore forte 'strong engine. This is partly because the adjective forte 'strong' is not a full-fledged sound lexeme; its meaning "loud" 


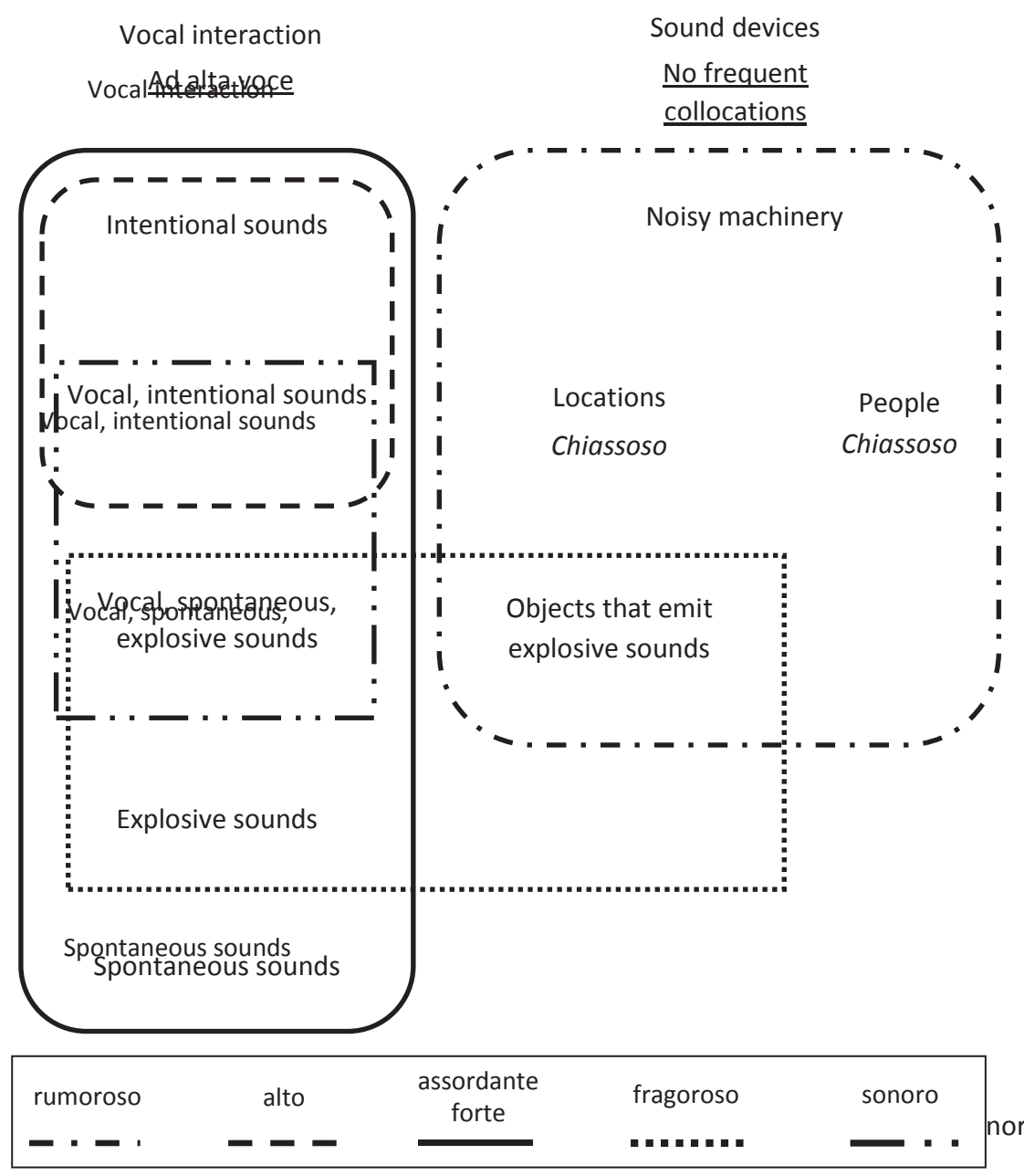

Figure 2. Semantic map of the field "Loud".

Note: The map contains 11 frames and five zones which show the distribution of lexemes in the field. The frames covered by chiassoso are marked with the word "chiassoso". The expression "ad alta voce" (in the frame "Vocal interaction") is underlined, as it is not part of the subject of research. No frequent collocations were found for the frame "Sound devices" (underlined on the map).

is metaphorical and therefore it cannot, for example, be a source for metonymic shifts. Metaphorical shifts with the meaning "loud" as the source for the metaphor are also restricted.

Alto (literally, 'high') is one of the main lexemes (along with forte 'strong') to denote loudness above the norm of Type A. However, while the typical collocations of forte 'strong' include almost all the nouns of this type, alto 'high' makes typical collocations only with the nouns that denote targeted acoustic phenomena: voce 'voice', grido 'shout, scream', musica 'music'. It can also collocate with the word suono 'sound'. Nouns denoting sounds that are usually spontaneous and do not have a target (e.g., rumore 'noise', battito 'knock', risata 'laughter') are unlikely to form collocations with alto 'high'. A related property of these sounds, which hypothetically makes them (or more specifically the nouns denoting them) unsuitable for collocations with alto 'high', is their brevity. As the meaning of loudness above the norm of alto 'high' is metaphorical, its use in metonymic shifts is also complicated. Thus it does not usually collocate with the Type B nouns. 
Other lexemes which are used for the Type A frames are sonoro and sonante, both denoting an intensive sound vibration ('ringing, sonorous'); however, sonante 'sonorous' is much less frequent, and assordante 'deafening' denotes an extreme level of loudness. Fragoroso 'uproarious' may cover the frames of both Type A and Type B: "Explosive noise", "Vocal, spontaneous, explosive sounds", "Explosive sounds". As seen from the names of the frames, the principal quality that this word denotes is explosiveness - hence such widespread collocations as cascata fragorosa 'deafening waterfall' and risata fragorosa 'uproarious burst of laughter'. Rumoroso 'noisy' is the main adjective for the Type B frames: "Locations", "Objects that emit explosive sounds", "People", "Noisy machinery". The meaning of the lexeme can be described as "making (extra) noise". The meaning is rather loose, deprived of shades of meaning proper to its quasi-synonyms fragoroso 'uproarious' and chiassoso 'noisy, rowdy'. Chiassoso 'noisy, rowdy' is used mostly with nouns denoting people (frame "People") or places with people (frame "Locations"). Clamoroso 'resounding, noisy' was found to collocate poorly with the stimuli and thus can be considered irrelevant for this field.

We notice that some physical characteristics tend to fuse: For example, the sensation of loudness is connected to such dynamic properties of a sound event as smoothness and explosiveness. This is also reflected in the new environmental psychophysics, which treats a perceived quality as a fusion of individual sensory qualities (Nosulenko \& Samoĭlenko, 2013, 2016).

\section{Conclusion}

The frame-based approach provides an effective means of studying the relationship between sensory qualia and their conceptualization in language. Frames serve as an intermediary link between the outside world and language, as situations that they denote, on the one hand, describe reality and, on the other, are defined by language.

The frame structure given in this study reflects a complex conceptual system of representations of the properties of sound phenomena. Primarily, language registers a substantial difference between characteristics of sounds proper (Type A) and characteristics of objects that emit sounds (Type B). Analysis of the field also showed the importance of such sound features as vocal/non-vocal, intentional/ spontaneous, explosive/non-explosive, one source/multiple sources. For objects and processes that emit sounds, their taxonomic class gains relevance (natural vs. artificial). The meanings of the Italian lexemes used to denote the qualities of the field (roughly corresponding to the English words loud and noisy) were specified.

These data can be seen as a contribution to the theory of object-relatedness of sensory experience (Barabanshchikov, 2019; Nosulenko, 2016). The loudness of a speech sound and the loudness of a closing door are assumed to represent different qualities, even when the sound wave amplitude of both sounds is the same. This is partially confirmed in psychophysical research (Huang \& Elhilali, 2017; Nosulenko \& Samoŭlenko, 2016).

The opposition found in this paper could be compared to the one that has emerged in the philosophical debate of recent years. According to one point of view, auditory experience is treated as sensations born in mind and detached from objects or phenomena that emit them (Maclachlan, 1989). Another point of view 
states that sounds are closely connected both to the outer world and to objects that emit them (O'Callaghan, 2014). Our findings show that not only sounds, but also their individual qualities, are distally located, event-like, and semantic phenomena.

We do not assert that the experience of sensory qualities is equal to their verbal designation. However, psychologists who analyze perception of the naturally sounding environment isolate perceived qualities on the basis of their verbal descriptions (Nosulenko \& Samoilenko, 2013). Classification of sounds and their qualities influences the perception and the experience of them: The loudness of intentional sounds is not equal to the loudness of spontaneous sounds, and noisy people are different from noisy mechanisms. The following explanation could be given: The experience of loudness is embedded in the global process of perception of the world, which is provided not only by sensory systems, but also by the knowledge stored in mental structures, representing past perceptual and mental experience.

\section{Limitations}

As the current paper investigates the field "Loud" only in one language, its results are, strictly speaking, relevant only for Italian. Although the findings could be seen as the basis for studying human cognitive structures, research on other languages is crucial for arriving at a well-grounded conclusion. Another limitation is the number of native speakers interrogated for the survey; more subjects will make the sample more representative. Another possibility for future research is to survey native speakers who are not trained in linguistics. Comparison between informed opinions of specialists and opinions based only on one's linguistic feeling could be of interest.

\section{References}

Agrillo, C. \& Roberson, D. (2009). Colour language and colour cognition: Brown and Lenneberg revisited. Visual Cognition, 17, 412-430. https://doi.org/10.1080/13506280802049247

Apresian, Iu.D. (1995). Izbrannye trudy. Tom 1: Leksicheskaia semantika [Selected works. Volume 1: Lexical semantics]. Moscow: Shkola «Lazyki russkoi kul'tury», Izdatel'skaia firma «Vostochnaia literatura» RAN.

Blinnikov, G.B. (2013). Semantika sensornykh kachestv na primere analiza upotrebleniia prilagatel'nogo «shershavyì v russkom i ital'ianskom iazykakh (Semantics of sensory qualities: A case study of the adjective "rough" in Russian and Italian). Vestnik Moskovskogo gosudarstvennogo lingvisticheskogo universiteta, 667(7), 43-55.

Blinnikov, G.B. (2015). Modelling synaesthetic transfer patterns: A case study of Italian and Russian adjectives. In Kognitivnoe modelirovanie v lingvistike: Trudy XVI-ı̌ Mezhdunarodno konferentsii "Kognitivnoe modelirovanie v lingvistike». CML-2015 [Cognitive modeling in linguistics: Proceedings of the XVI International Conference on Cognitive Modeling in Linguistics, CML-2015] (pp. 40-48). Rostov-on-Don: Fond nauki i obrazovaniia.

Baskakova, E.A. (2015). Leksicheskaia tipologiia kak instrument dliia sozdaniia universal'nogo slovaria: priznaki "tugor" i "uprugii" [Lexical typology as a universal vocabulary tool: A case study of the qualities "tight" and "elastic"]. Vestnik Voronezhskogo gosudarstvennogo universiteta. Seriia: Lingvistika I mezhkul'turnaia kommunikatsiia, 3, 132-136.

Barabanshchikov, V.A. (2019). Obshchaia psikhologiia: Psikhologiia vospriiatiia [General psychology: Psychology of perception]. 2nd ed. Moscow: Izdatel'stvo Iurait.

Berlin, B. \& Kay, P. (1969). Basic color terms: Their universality and evolution. Berkeley: University of California Press. 
Burchardt, A., Erk, K., Frank, A., Kowalski, A., Padó S., \& Pinkal, M. (2009). Using FrameNet for the semantic analysis of German: Annotation, representation, and automation. In H.C. Boas (Ed.), Multilingual FrameNets: Methods and applications (pp. 209-244). Berlin/New York: Mouton de Gruyter.

Candito, M., Amsili, P., Barque, L., Benamara, F., de Chalendar, G., Djemaa, M., Haas, P. ... Vieu, L. (2014). Developing a French FrameNet: Methodology and first results. In LREC - The 9th edition of the Language Resources and Evaluation Conference, May 2014, Reykjavik, Iceland (pp. 1372-1379).

Chalmers, D.J. (1996). The conscious mind. Oxford: Oxford University Press.

Dennett, D.C. (1991). Consciousness explained. Boston: Little, Brown and Company. https://doi. org/10.2752/174589311X12893982233713.

Duro, A., \&Della Valle, V. (2008). Il vocabolario Treccani. Rome: Istituto della Enciclopedia Italiana.

Fillmore, C.J. (1977). The case for case reopened. Syntax and Semantics, 59-81.

Fontenelle, T. (1997). Using a bilingual dictionary to create semantic networks. International Journal of Lexicography, 10(4): 275-303. https://doi.org/10.1093/ijl/10.4.275

Fuller, G., Stecker, R., \& Wright, J.P. (2000). John Locke: An essay concerning human understanding in focus. London: Routledge.

Heid, U. (1996). Creating a multilingual data collection for bilingual lexicography from parallel monolingual lexicons. In Proceedings of the VIIth EURALEX International Congress (pp. 573-559).

Jackson, F. (1982). Epiphenomenal qualia. Philosophical Quarterly, 32, 127-136. https://doi. org/10.2307/2960077

Kashkin, E.V. (2013). Prilagatel'nye, opisyvaiushchie svoistva poverkhnostei: k postroeniiu tipologii (na materiale prilagatel'nykh nalichiia nerovnostei v ural'skikh iazykakh). [Adjective descriptors of surface qualities: Towards a typology (A case study of adjectives that describe surface irregularities in Uralic languages)]. In R. Guzmán Tirado \& I. Votyakova (Eds.), Tipologíaléxica (pp. 115-122). Granada: Jizo Ediciones.

Keil, Ch., Blau, D., Keil, A.V. \& Feld, S. (2002). Bright Balkan morning: Romani lives and the power of music in Greek Macedonia. Middletown, CT: Wesleyan University Press.

Kilgarriff, A., Baisa ,V., Bušta, J., Jakubíček, M., Kovář, V., Michelfeit, J. ... Suchomel, V. (2014). The Sketch Engine: Ten years on. Lexicography: Journal of ASIALEX, 1(1), 7-36. https://doi. org/10.1007/s40607-014-0009-9

Kobozeva, I.M. (2000). Lingvisticheskaia semantika: Uchebnoe posobie. [Linguistic semantics: A study guide]. Moscow: Ėditorial URSS.

Kuznetsov, A.M. (1990). Pole [Field]. In V.N. Iartsevoi (Ed.), Lingvisticheskii éntsiklopedicheskii slovar' [Linguistic encyclopedic dictionary] (pp. 380-381). Moscow: Sovetskaia entsiklopediia.

Lakoff, G. \& Johnson, M. (2008). Metaphors we live by. Chicago: University of Chicago Press.

Le Guen, O. (2011). Materiality vs. expressivity: The use of sensory vocabulary in Yucatec Maya. Senses \& Society, 6(1), 117-126. https://doi.org/10.2752/174589311X12893982233993

Levinson, S.C. \& Majid, A. (2014). Differential ineffability and the senses. Mind and Language, 29, 407-427. https://doi.org/10.1111/mila.12057

Lindén, H.H., Luukkonen, J., Laine, A.O., Roivainen, H., \& Väisänen, N. (2017) Finn FN 1.0: The Finnish frame semantic database. Nordic Journal of Linguistics, 40(3) https://doi.org/10.1017/ S0332586517000075

Luraghi, S. (2015). Asymmetries in Italian temperature terminology. In M. Koptjevskaja-Tamm (Ed.), Typological studies in language (Book 107). Linguistics of temperature. (pp. 334-353). Amsterdam/ Philadelphia: Benjamins. https://doi.org/10.1075/tsl.107.11lur

Maclachlan, D.L.C. (1989). Philosophy of perception. Englewood Cliffs, NJ: Prentice Hall.

Nosulenko, V.N. (1988). Psikhologiia slukhovogo vospriiatiia [Psychology of auditory perception]. Moscow: Nauka. 
Nosulenko, V.N. \& Samoilenko, E.S. (2013). Rekonstruktsiia vosprinimaemogo kachestva akusticheskogo sobytiia po ego verbal'nym opisaniiam [Reconstruction of a perceived quality of an acoustic event by its verbal description]. Eksperimental'naia psikhologiia [Experimental Psychology], 6(3), 74-82.

Nosulenko, V.N., \& Samoilenko, E.S. (2016). «Eksperimental'naia real'nost'» sovremennoi ekologicheskoi sredy. ["Experimental reality" of the contemporary ecological environment]. In V.I. Panov (Ed.), Ekopsikhologicheskie issledovaniia-4 [Ecopsychological Research 4] (pp. 93-108). Moscow, Saint Petersburg: Nestor-Istoriia.

O'Callaghan, C. Audible independence and binding (2014). In R. Brown (Ed.), Consciousness inside and out: Phenomenology, neuroscience, and the nature of experience. Studies in brain and mind, Vol. 6 (pp. 335-341). Dordrecht: Springer. https://doi.org/10.1007/978-94-0076001-1_22

Ohara, K. (2015). Construction building as a practical implementation of construction grammar and frame semantics: Japanese FrameNet. Poster at the 13th International Cognitive Linguistics Conference (ICLC 13), Northumbria University at Newcastle. John Benjamins Publishing Company.

Rakhilina, E.V. \& Prokof'eva, I.A. (2004). Rodstvennye iazyki kak ob"ekt leksicheskoi tipologii: russkie i pol'skie glagoly vrashcheniia [Related languages as an object for a lexical typology: Russian and Polish verbs of rotation].Voprosy iazykoznaniia, 1, 60-78.

Rakhilina, E.V. \& Reznikova, T.I. (2013). Freimovyi podkhod k leksicheskoĭ tipologii [A frame approach to lexical typology]. Voprosy iazykoznaniia, 2, 3-31.

Rakhilina, E. (2016). A Frame-based methodology for lexical typology. In P. Juvonen \& Maria Koptjevskaja-Tamm (Eds.), The lexical typology of semantic shifts (pp. 95-131). Berlin, Boston: Mouton de Gruyter. https://doi.org/10.1515/9783110377675-004

Rundell, M. (2012). MacMillan English dictionary for advanced learners. London: MacMillan/A. \& C. Black.

Ruppenhofer, J., Boas, H.C., \& Baker, C.F. (2017). FrameNet. In P.A. Fuertes-Olivera (Ed.), The Routledge handbook of lexicography (pp. 383-398). New York: Routledge. https://doi. org/10.4324/9781315104942-25

Salomão, M., Torrent, T.T. \& Sampaio, T.F. (2013). A linguística de corpus encontra a linguística computacional: Notícias do projeto FrameNetBrasil. Cadernos de Estudos Linguísticos, 55(1), 7-34. DOI: https://doi.org/10.20396/cel.v55i1.8636592

Senft, G. (1987). Kilivila colour terms. Studies in Language, 11(2), 313-346. https://doi. org/10.1075/sl.11.2.03sen

Tyler, St.A. (1986). Post-modern ethnography: From document of the occult to occult document. In J. Clifford \& G.E. Marcus (Eds.), Writing culture: The poetics and politics of ethnography (pp.122-140). Berkeley, CA: University of California Press.

Vygotsky, L.S. (1978). Mind in society: The development of higher psychological processes. Cambridge, Mass.: Harvard University Press. (Original Russian pieces were published in 1930.)

Wierzbicka, A. (2010). Experience, evidence, and the hidden cultural legacy of English. Oxford University Press.

Wittgenstein, L. (1953). Philosophical investigations. New York: Macmillan.

Original manuscript received December 27, 2018

Revised manuscript accepted January 10, 2019

First published online March 15, 2019

To cite this article: Blinnikov, G.B. (2019). Conceptualization of the Sensory Experience: A FrameBased Approach. Psychology in Russia: State of the Art, 12(1), 147-162. DOI: 10.11621/pir.2019.0111 